\title{
The Implicit Theory of Mind in the Dependence on Psychoactive Substances and under Standard Conditions
}

\section{Імпліцитна теорія свідомості при залежності від психоактивних речовин та в умовах норми}

\section{Oleksandr Telcharov}

Postgraduate Student of the Department of Psychodiagnostics and Clinical Psychology, Taras Shevchenko National University of Kyiv, Kyiv (Ukraine)

ORCID ID: https://orcid.org/0000-0002-3381-6693

e-mail: oleksandr.telcharov@gmail.com

\section{Олександр Тельчаров}

Аспірант кафедри психодіагностики та клінічної психології, Київський національний університет імені Тараса Шевченка, м. Київ (Україна)

\section{ABSTRACT}

The aim of the article is to compare the features of Theory of Mind between people dependent on psychoactive substances, at different stages of recovery and the group of conditional norm.

98 individuals participated in the research. In the study, the following groups were compared by different parameters: 1) persons dependent on psychoactive substances. This group includes patients of the rehabilitation center, i. e. people in the early stages of recovery who are dependent on alcohol and / or other psychoactive substances; 2) persons dependent on alcohol which are part of the previous group; 3) persons addicted to alcohol, at later stages of recovery.

Address for correspondence, e-mail: kpnu_lab_ps@ukr.net Copyright: (c) Telcharov Oleksandr

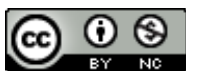

The article is licensed under CC BY-NC 4.0 International

(https://creativecommons.org/licenses/by-nc/4.0/)

(C) Telcharov Oleksandr

DOI (article): https://doi.org/10.32626/2227-6246.2021-52.225-252 
This group includes members of the Alcoholics Anonymous community; 4) persons belonging to the group of conditional norm.

Methods. There were used such instruments as Theory of Mind assessment scale (Th.o.m.a.s, Bosco, Gabbatore, Tirassa \& Testa, 2016); Toronto Alexithymia Scale TAS26, adapted by Bekhterev Psychoneurological Research Institute (Eresko, Isurina, Koidanovskaia, Karvasarskyi, Karpova, Korepanova \& Shifrin, 2005); 5PFQ personality questionnaire, adapted by Hromov (Hromov, 2000). For further analysis, descriptive statistics as well as several non-parametric criteria (U-Mann-Whitney test; Kolmogorov-Smirnov criterion) has been used.

The results. A number of statistically significant differences were found between the 4 groups. In particular, differences were found in ToM structure, in the severity of alexithymia, as well as in the strength of the manifestation of various factors and subfactors by the personal questionnaire 5PFQ. The complexity of the allocative perspective has been established in both groups of dependent persons, in patients of the rehabilitation center and within the group of Alcoholic Anonymous. It was found that these two groups are not statistically different in the Toronto alexithymic scale, although in both groups there are high median indicators, which are moderately higher the upper limit of normal scores, and there is a statistically significant difference between these groups and the conditional norm group.

Conclusions. ToM of persons dependent on psychoactive substances is characterized by a reduced understanding of their own emotions, if usage of psychoactive substances continues or has stopped recently, but it is resumed over the term of sobriety; while a high rate of alexithymia is remained. Also, persons dependent on psychoactive substances have a complication of the allocative perspective of ToM, even during the long-term sobriety.

Key words: persons dependent on psychoactive substances, Alcoholic Anonymous members, Theory of Mind, alexithymia, allocative perspective, personality factors.

\section{Introduction}

High rates of dependence on psychoactive substances (hereinafter - DPAS), which have been recorded in recent decades (Pinchuk, Kolodezhnij \& Zdorik, 2017), as well as significant psychological, social and economic consequences of this problem encourage researchers to seek new constructs and (C) Telcharov Oleksandr

DOI (article): https://doi.org/10.32626/2227-6246.2021-52.225-252 
approaches that could help to slow down this dangerous tendency. Theory of Mind (hereinafter - ToM) is one of those constructs. Since the psychological phenomenon denoted by this concept provides a significant part of the effects of mutual understanding and effective interaction between people, it can be considered as a factor that impacts psychological well-being and, in the case of mental problems, the quality and duration of remission.

Theory of Mind (Premack \& Woodruff, 1978) (Dubyaga \& Mescheryakov, 2010) is the ability to explain and attribute mental states - beliefs, desires, emotions, knowledge, etc. - to oneself and others, as well as the understanding that others have beliefs, desires, intentions and attitudes that are different from their own.

Because of ToM higher primates and humans interact socially when analyzing, evaluating, and trying to understand the behavior of others (Gweon \& Saxe, 2013).

Persons who are dependent on psychoactive substances show reduced ToM. For instance, this was described in the meta-analysis (Onuoha, Quintana, Lyvers \& Guastella, 2016) in which the affective deficit of ToM in persons addicted to alcohol is recorded first of all. Researchers conclude that the cause of this deficiency is damage in certain areas of the brain due to long-term alcohol consumption. Interestingly, the results did not depend on factors such as education and intelligence of the subjects. Today it has been established that people addicted to alcohol have a tendency to inadequate perception and assessment of other people's emotions, which highlights the importance of clarifying the obtained scientific facts and finding ways to correct the affective deficit of ToM in persons dependent on psychoactive substances.

A number of authors describe in detail the phenomenon of dependence on psychoactive substances, psychological and neurophysiological mechanisms, as well as changes in personality associated with the usage of psychoactive substances and in- 
DOI: https://doi.org/10.32626/2227-6246.2021-52

2021. випуск 52

dividual psychological traits of persons dependent on psychoactive substances (Haponov, 2018; Darvishov, 2019; Minko, Lisna \& Markozova, 2018; Chemerys, 2017; Minnaard, 2020; Svanberg, 2018).

Other authors have thoroughly studied the features of the affective sphere in persons addicted to surfactants and other disorders, established certain dependencies on the identified changes in affective processes, in particular, the manifestation of alexithymia (Voznyi, 2013; Husak, Martyniuk \& Sydoruk, 2013; Martsenkovskyi \& Martsenkovska, 2019).

N. Burmaka (2003) has found in groups of adolescents and youth, dependent on alcohol, alexithymic symptom complex, with a "high threshold of actualization of emotionality", which is reflected in the reduction of emotional profile and semantic transformation of emotionality. The author concludes about the role of alexithymia as a psychological mechanism for the formation the forms of dependence, which are associated with overcoming infantile traumatic experience. L. Shcherbyna's study (2004) revealed two variants of structural reorganization of the motivational-meaning trait of persons dependent on psychoactive substances in the period of complete remission: further formation of maturity of motivation-meaning trait or retardation reduction of its restructuring processes.

Other researchers have outlined the main methods and results of the study of ToM under normal conditions and pathology (Sprong, Schothorst, Vos, Hox \& Engeland, 2007; Gweon \& Saxe, 2013; Schiffer, Pawliczek, Müller, Wiltfang, Brüne, Forsting \& Hodgins, 2017; Jacobs \& Nader-Grosbois, 2020).

At the same time, in the literature there is practically no data of results of research on features of ToM and its various components at the persons dependent on psychoactive substances, different from alcohol (Onuoha, Quintana, Lyvers \& Guastella, 2016).

It should be noted that the research of aspects related to the dynamics of ToM in the process of recovery from DPAS (c) Telcharov Oleksandr

DOI (article): https://doi.org/10.32626/2227-6246.2021-52.225-252 
and the establishment of connections between ToM and personal factors remains relevant.

The aim of the article is to compare the features of ToM in persons dependent on psychoactive substances at different stages of recovery to the group of conditional norms.

\section{The tasks of this article}

1. To identify the features of ToM, and related alexithymia and personality factors of persons dependent on psychoactive substances at different stages of recovery, as well as those features in the group of conditional norm.

2. To identify differences in the studied parameters between subgroups of the sample.

3. Based on the obtained results, to formulate hypotheses that can be tested in further investigations.

\section{Research methods}

When studying ToM in persons dependent on psychoactive substances, we followed certain rules determined by peculiarities of this sample: 1) reduced ability to self-regulation, which is observed in these persons due to congenital features and damage to areas of the neural substrate responsible for executive functions, as well as areas that are considered to be correlates of ToM and emotional intelligence; 2) low motivation to participate in a study; 3) high reactivity, 4) possible complications of cognitive processes due to recent prolonged intoxication.

All of the above mentioned issues negatively affect the ability to undergo psychological research effectively, they can be expressed in increased fatigue, inability to concentrate for a long time, the tendency to random or simple answers, partial or complete inability to understand some test tasks etc. To solve and partially control these features, we chose the tools that, in our opinion, were the most appropriate for comprehensive research and obtaining high quality data. Such tools

(C) Telcharov Oleksandr

DOI (article): https://doi.org/10.32626/2227-6246.2021-52.225-252 
DOI: https://doi.org/10.32626/2227-6246.2021-52

2021. випуск 52

should be as short as possible, providing an opportunity to assess the personal characteristics of the subject, previously used and adapted in the clinical sample.

To measure ToM in persons dependent on psychoactive substances, we used Theory of Mind assessment scale, abbreviated - Th.o.m.a.s. (Bosco, Capozzi, Colle, Marostica \& Tirassa, 2014; Bosco, Gabbatore, Tirassa \& Testa, 2016). Taking into account the connection between the dependence on psychoactive substances and the negative impact of this factor on areas of the brain, the peculiarities of which are considered to be correlates of ToM and emotional intelligence, we also included the Toronto Alexithymic Scale TAS26, adapted in Bekhterev's Research Institute (Eresko, Isurina, Koidanovskaia, Karvasarskii, Karpova, Korepanova \& Shifrin, 2005). TAS is used to measure how preserved is the ability to recognize their own emotions and bodily sensations, emotional response, as well as the ability to understand the emotions of others and the ability to put yourself in the place of another invested in the conceptual field of emotional intelligence.

Taking into account the functioning of ToM and its manifestations in behavior largely depends on personal characteristics, we also used the Five-Factor Personality Questionnaire 5PFQ, adapted by Hromov (Hromov, 2000).

Th.o.m.a.s. is a questionnaire consisting of 39 open-ended questions (some of them are optional, so in fact there are 37 questions in the test), which are aimed to explore various features of ToM.

The procedure of passing this test is quite simple: the researcher offers a number of questions to which the respondent answers as he / she wants. If the subject has difficulties, the researcher can pay attention to this and try to paraphrase the question (without creating bias). Then the answers must be transferred from qualitative data into a quantitative scale. In the original version, the form of the procedure is a semi-struc(c) Telcharov Oleksandr

DOI (article): https://doi.org/10.32626/2227-6246.2021-52.225-252 
DOI: https://doi.org/10.32626/2227-6246.2021-52

2021. випуск 52

tured interview, during which the conversation is recorded and then given to two assistants who did not participate in the interview. The assistants independently encode the answers into a scale, after this the results are compared. Taking into account the existing realities in hospitals and rehabilitation centers, we modified the procedure, namely: it was proposed to the subjects in the form of a subjective questionnaire in a battery of three tests and a short questionnaire. The study was conducted in small groups to ensure the ability to record behavioral characteristics and help the respondents in case of any difficulties with passing the test. Groups of people at a later stage of recovery and conditionally healthy ones were provided with online questionnaires.

The answer to each question can be evaluated from 0 to 4 points, depending on the characteristics of the respondent's result.

\section{Score of 0 points is given:}

- in case the subject is silent, although the interviewer encourages him / her to answer;

- in case the answer is incomprehensibly confused, or has absolutely nothing to do with the question, or detached from reality.

\section{Point 1 is given:}

- in case the subject spends time, but in fact did not provide any meaningful answer;

- in case the subject says that he does not know how to answer, or is limited to answers yes or no, without adding anything more significant;

- in case the answer is confusing or contradictory regarding the question;

- in case the subject provides an example (involuntarily, or after the request of the researcher), which does not correspond to the answer itself.

$A$ score of 2 points is given under the following conditions:

(C) Telcharov Oleksandr

DOI (article): https://doi.org/10.32626/2227-6246.2021-52.225-252 
DOI: https://doi.org/10.32626/2227-6246.2021-52

2021. випуск 52

- the answer gives the feeling that the subject is «confused», although he gives the correct answer;

- it is simply a repetition of a question without further development or explanation (for example, a tautological answer);

- the subject expresses an emotional tone that does not answer the question (for example, an emotionally positive answer to a question about negative emotions);

- it is incorrectly conformed with the perspective required by the question, for example, when the question concerns the emotional states of another person (allocentric perspective), and the answer concerns only the subject him / herself (egocentric perspective).

\section{A score of 3 points is given if:}

- the answer is clearly formulated and consistent, but provided with difficulty, or not extensive (if in the form of an interview, then after several attempts by the interviewer to clarify);

- the context corresponds to the question, but does not have a specific, meaningful example;

- a provided example is approximate, general, meaningless or relates only to behavior and not to mental states or events;

- the answer is coherent and consistent, but general, stereotypical or only slightly contextualized.

A score of 4 points is assigned to the answer that:

- is coherent, detailed and organized, with meaningful, coherent and contextualized examples;

- refers differently to the subject's own mental states and events, as well as to the events of others, thus providing not a general or dry answer, but a contextualized one that is relevant to the personal experience of the respondent.

To get a score of 4 , it is not necessary to give an example based on personal experience: it is enough that the answer is contextualized in a sufficiently detailed manner, that there are (c) Telcharov Oleksandr

DOI (article): https://doi.org/10.32626/2227-6246.2021-52.225-252 
DOI: https://doi.org/10.32626/2227-6246.2021-52

2021. випуск 52

clear gradations of understanding the question, and the example or answer reflects questions from several sides.

\section{Test scales:}

Scale A: I-Me - questions are in the area of understanding one's own emotions and their impact on the respondent, how well a person understands his / her own emotional states, desires, can affect his / her own emotional state (egocentric perspective), hereinafter ToMA.

Scale B: Other-Self - questions lie in the area of how well the respondent understands other people's emotional states and how they are reflected in the respondent's behavior, how well the respondent can represent emotional states, other people's desires, and whether people can influence other people's conditions (allocative perspective), hereinafter ToMB.

Scale C: I-Other - questions lie in the area of how a person relates to hypothetical others and whether he / she understands the change in their emotional experiences, whether a respondent can put him / herself in place of another person and imagine what that person can feel or want. The scale also is related to whether a respondent can influence the emotional states and desires of another person (egocentric perspective), hereinafter ToMC.

Scale D: Other-Me - questions lie in an area of how the respondent thinks about the attitude of others to his / her emotional states, experiences and behavior of others towards him (allocative perspective), hereinafter ToMD (Bosco, Gabbatore, Tirassa \& Testa, 2016).

\section{Results and discussions}

Overview of the study sample. 98 individuals took part in the study at different stages of recovery. Among them 42 people are ones dependent on psychoactive substances at the initial stage of recovery (27 people addicted to alcohol and 15 - dependent on other psychoactive substances). At the time when this survey was done, they were treated at the Medlux 
DOI: https://doi.org/10.32626/2227-6246.2021-52

2021. випуск 52

Rehabilitation Center in Kyiv. All subjects have had an episode of long-term use of psychoactive substances no more than 3 weeks before the study, which was a mandatory criterion for the homogeneity of the sample. All subjects were included into one of three following categories: 1) dependence on alcohol (ICD code F10); 2) dependence on stimulants (ICD code F15); 3) dependence on the simultaneous use of several drugs (ICD code F19.2). The survey was conducted in person, in small groups in several stages.

Also as a control group we involved people (15 people) who had a history of previous episodes of long-term and systematic use of $\mathrm{s}$ psychoactive substances in the past, but for a long time (from 1 month or more, maximum 15 years) are now sober, are on the further stage of recovery, comparing to the previous group, and do not accept any psychoactive substances. All subjects of the control group are representatives of the Ukrainian Alcoholics Anonymous community. The study was conducted remotely in the form of an e-survey due to quarantine restrictions.

Another group of comparison (41 people), were the subjects assigned to the group of conditional norm. There are people without any dependencies on psychoactive substances or gambling. The study was also conducted remotely in this group.

In the study, the following groups were compared by different parameters.

1. People dependent on psychoactive substances. This group includes patients of the rehabilitation center, i. e. people in the early stages of recovery who are dependent on alcohol and / or other psychoactive substances. This group will be abbreviated hereinafter as DPAS.

2. People dependent on alcohol that are part of the DPAS group. This group will be abbreviated as DA.

3. People addicted to alcohol, at later stages of recovery. This group includes members of the Alcoholics Anonymous community, abbreviated AA.

(C) Telcharov Oleksandr

DOI (article): https://doi.org/10.32626/2227-6246.2021-52.225-252 
DOI: https://doi.org/10.32626/2227-6246.2021-52

2021. випуск 52

4. Persons belonging to the group of conditional norm. This group will be denoted by $\mathrm{CN}$.

Gender distribution of the sample: 53 males and 45 females. In particular, in the subgroups the distribution is as follows. Among the DPAS group, 34 are males and 8 are females. Among the AA group, 14 are males and one is a female. CN group: 36 females and 5 males. Unfortunately, there is gender inhomogeneity between groups. Most people dependent on psychoactive substances are males, and the control group of the conditional norm mostly consists of females, so there is a possible influence of gender. This can be attributed to the prospects for further research. However, it should also be noted that the main control group (AA) also mainly consists of males, so in comparison with these groups, results are not influenced by gender.

Distribution of the sample by dependence on a specific type of a psychoactive substance: 27 people were assigned to the group of Dependent on Alcohol (F10), 5 persons - to the group of Dependent on Stimulators (F15), and 13 - to a group of Dependence on multiple psychoactive substances (F19.2). It is also worth noting that three subjects were diagnosed with dependence on several drugs in combination with alcohol consumption, which is reflected in the study.

Distribution of the sample by age: subjects under study were persons aged 19 to 70 years, median -35 years, SD $=14.2$. One third of the sample $(35.7 \%)$ is in the range of $20-22$ years, and $81.6 \%$ is in the range of 20 to 50 years. Although the sample is not generally homogeneous in terms of age, because there is a predominance of respondents aged 20-22 years (mostly a group belonging to the conditional norm), other age categories are widely represented. We assume that the age factor may have an impact, but this impact may not be very significant.

Verification of the normality of the sample distribution: since the study was conducted on three groups which were se- 
DOI: https://doi.org/10.32626/2227-6246.2021-52

2021. випуск 52

lected according to certain criteria, we assume that the sample will not meet the normal distribution criterion. For verification we use the nonparametric Kolmogorov-Smirnov criterion. According to the results of applying the Kolmogorov-Smirnov criterion (the results were checked according to the main variables, namely according to the TAS 26, 4 scales of the Th.o.m.a.s test and the main factors 5PFQ), it was found that according to 6 scales out of 11 the sample corresponds to normal distribution (Sig. 2 tailed $>0.05$ ), the exceptions are the results on the ToMA scale (I-Me), (sig. 2 tailed =0.021); on the scale of ToMC (I-Other), (sig. 2 tailed $=0.011$ ); on the scale ToMD (Other-Me), (sig. 2 tailed = 0.028); according to the second (Separation - Attachment) (sig. 2 tailed =0.029) and third (Impulsivity - Self-control) (sig. 2 tailed $=0.005$ ) factors of the 5PFQ questionnaire.

Taking into consideration findings described above, we consider it appropriate to use non-parametric methods of statistical processing, because the distribution of almost half of the basic parameters differs from normal. Another factor that determines the use of non-parametric methods is the fact that part of the study sample belongs to the clinical group. Furthermore, the sample size of the experimental and control groups is relatively small (27 and 15 people, respectively). Therefore, we use U - Mann-Whitney test to check a statistically significant difference between groups.

The differences between the $D A$ group $(N=27)$ and the $A A$ control group $(\mathrm{N}=15)$. As a result, the differences between these groups were determined by the Th.o.m.a.s test scale ToMA ( $\operatorname{sig}=0.002)$, the fifth factor of the 5PFQ (Pragmatism - Expressiveness), ( $\mathrm{sig}=0.02)$, and the second subscale of the fifth factor 5PFQ (Realism - Curiosity), ( $\operatorname{sig}=0,001)$.

The differences between the DPAS group $(N=42)$ and the $C N$ group $(\mathrm{N}=41)$. As a result, differences were found in the indicators of the Alexithymia TAS 26 questionnaire, in the Th.o.m.a.s test (integrative result and all four ToM (c) Telcharov Oleksandr

DOI (article): https://doi.org/10.32626/2227-6246.2021-52.225-252 
scales), ( $\operatorname{sig}=0.000)$. Differences were also found in a number of scales of the $5 \mathrm{PFQ}$ questionnaire, namely on the 5th scale (Pragmatism - Expressiveness); the fifth subscale of the first factor (Avoidance of attention - attraction of attention); the fifth subscale of the fourth factor (Emotional stability - Emotional lability); the second subscale of the fifth factor (Realism - Curiosity); the third subscale of the fifth factor (Lack of artistry - Artistry); the fourth subscale of the fifth factor (Insensitivity - Sensitivity); and the fifth subscale of the fifth factor (Rigidity - Plasticity).

The differences between the $U N$ group $(N=41)$ and the $A A$ group $(N=15)$. As a result, several statistically significant differences were found between the groups, namely in the alexithymia parameter, as well as in the Th.o.m.a.s test (integrative result and three ToM scales, namely ToMB, ToMC, and ToMD). On the first scale, the difference is statistically insignificant.

Based on the above mentioned issues, we can notice the following. The structure of ToM differs significantly between dependent on psychoactive substances individuals and individuals without any dependencies identified. This also applies to the affective sphere (the level of alexithymia in dependent persons) and personal characteristics, in particular, emotional self-regulation, as well as attitudes to changes in the environment and readiness for change.

At the same time, the DA group also differs in the structure of ToM in comparison with the AA group. In particular, according to the ToMA scale, there is a difference in understanding a person's own emotions, feelings, attitudes and beliefs, as well as the curiosity factor. One of the groups is more open to active perception of the surrounding world, including the social one. However, no statistically significant difference on the alexithymia scale was found. This means that the level of alexithymia (i. e. preservation of the ability to understand one's own experiences and physiological manifestations) dif- 
DOI: https://doi.org/10.32626/2227-6246.2021-52

2021. виПУСК 52

fers significantly in the DPAS group (even under conditions of prolonged sobriety) from the similar level in the CN group. The fact that the fifth factor of the $5 \mathrm{PFQ}$ is statistically different in the DPAS group and other groups, taking into account the change in values towards the median indicators of relatively healthy individuals, in our assumption, may indicate some adaptation, i.e. such individuals become healthier. To follow in details how exactly these results differ, see the median values of statistically different indicators in each group.

Table 1 shows the median values of the test result for measuring ToM among four groups: 1) DPAS; 2) DA; 3) AA; 4) $\mathrm{CN}$.

Table 1

Median values of the ToM test

\begin{tabular}{|c|c|c|c|c|c|c|}
\hline Group & $\mathbf{N}$ & ToM Integrative & ToMA & ToMB & ToMC & ToMD \\
\hline DPAS & 42 & 2.1 & 2.3 & 2 & 2.1 & 1.8 \\
\hline DA & 27 & 2 & 2.2 & 2 & 2.1 & 1.8 \\
\hline AA & 15 & 2.3 & 2.9 & 2 & 2.2 & 1.7 \\
\hline CN & 41 & 2.7 & 3.1 & 2.8 & 2.6 & 2.3 \\
\hline
\end{tabular}

Note: ToM integrative is the indicator of the general level of ToM; ToMA - level of ToM on scale A (I-Me); ToMB - level of ToM on scale B (Other-Self); ToMC - level of ToM on scale C (I-Other); ToMD - level ToM on a scale of D (Other-Me).

According to the procedure of analysis of the Th.o.m.a.s test, each answer of the subject can have from 0 to 4 points. These points are added, and the average values for each scale are calculated, so the maximum value that can be obtained is 4 points. As we see in Table 1, the obtained data differs significantly in the three groups, while in the groups DA and DPAS the results are nearly the same. It should be noted that although we have modified the procedure for testing ToM using this technique, the general trends in dependent persons coincide with the results of the study of the authors of this (c) Telcharov Oleksandr

DOI (article): https://doi.org/10.32626/2227-6246.2021-52.225-252 
test (Bosco et al., 2014), although there is a relatively strong artifact lowering the score of the ToMD scale, as well as the subjects surveyed by us both in person and in the form of an online survey, on average scored less points than those studied by the authors of the method. This may be due to the specifics of the sample, or also influenced by the factor of modification of the ToM measurement procedure.

As we can see, according to the ToMA (I-Me) scale, the group DA, which has only recently stopped taking psychoactive substances, understands their own emotions, feelings, desires much worse than people who have not used psychoactive substances for a long time (group AA): median values are 2.2 and 2.9 respectively. Median indicators on other scales are nearly identical. This means the following pattern: both representatives of the DPAS and DA groups, who are in the early stages of recovery, and representatives of the AA group have difficulty in understanding the emotions of others, allocative perspective in general (after all, a score of 2 points is usually obtained when the answer is egocentric or inaccurate).

In addition, we see a difference in the ToMA score between the groups at early stages of recovery (DPAS and DA) and the group in the later stage of recovery (AA). Thus, in the AA group the median value is 2.9 points, in contrast to 2.1 and 2 (DPAS, DA), which demonstrates that people who do not use psychoactive substances for a long time have a higher level of understanding of their emotions, feelings, body sensations and beliefs than those people who have recently stopped taking psychoactive substances. Although subjects under study understand their own emotions better, the study shows that they have difficulties in understanding emotions, experiences, etc. of the other people. We can see this tendency both in people who have recently taken psychoactive substances and in people who have been sober for a long time. Unfortunately, we cannot claim the influence of the factor of alcohol consumption, because such persons could have, for example, congenital fea(C) Telcharov Oleksandr

DOI (article): https://doi.org/10.32626/2227-6246.2021-52.225-252 
DOI: https://doi.org/10.32626/2227-6246.2021-52

2021. випуск 52

tures that cause both difficulties in understanding other people and a tendency to drink alcohol.

Although, based on the results of the ToMA scale, we can assume that the lack of alcohol consumption has a positive effect on the understanding of a person's own affective and bodily manifestations. As we can see, the main trend reflected in the results is the problem of allocative perspective of ToM (difficulty or inability to put oneself in someone's place, look at the situation from the outside, from the position of another person) in people addicted to psychoactive substances, even with prolonged sobriety. The results on allocative scales are lower than similar results on conditionally egocentric scales. The egocentric perspective is reflected in the ToMA and ToMC scales, the allocative perspective is illustrated by the ToMB and ToMD scales.

See the analysis of the alexithymia parameter. Fig. 1 shows a comparative diagram of the median values of the TAS 26 test in four groups: 1) DPAS; 2) DA; 3) $\mathrm{AA}$; 4) $\mathrm{CN}$.

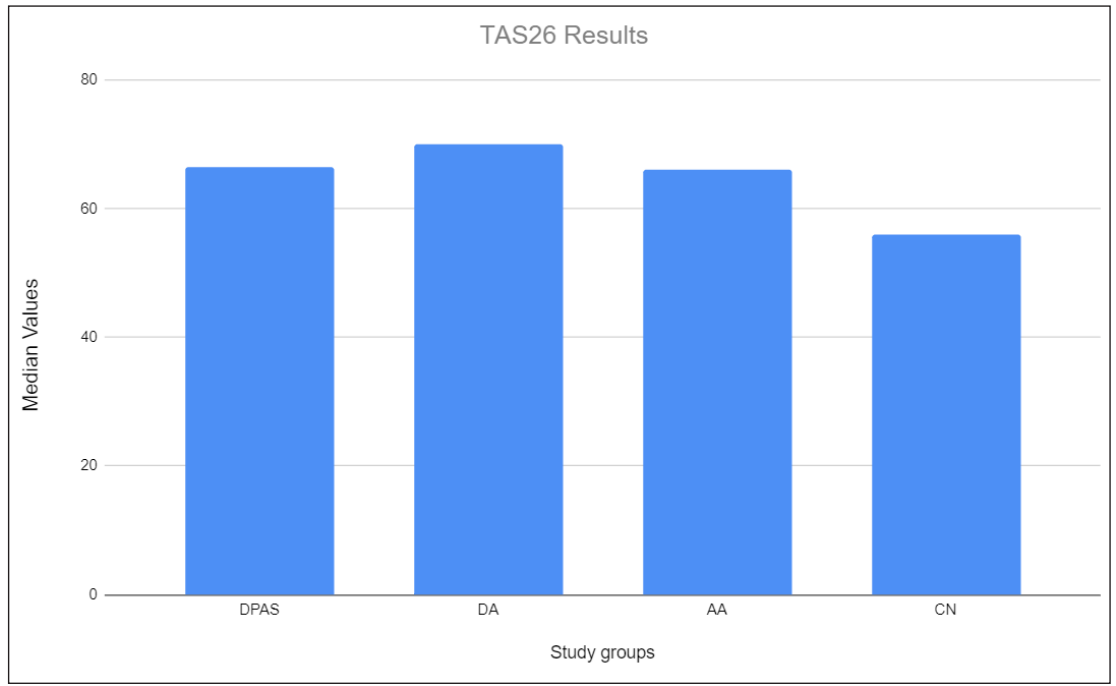

Fig. 1. Median meanings of Toronto Alexithymia Scale (C) Telcharov Oleksandr

DOI (article): https://doi.org/10.32626/2227-6246.2021-52.225-252 
DOI: https://doi.org/10.32626/2227-6246.2021-52

2021. випуск 52

According to the results of the alexithymia test, three groups of four have a median value higher than the maximum normal rate set by this test (up to 62 points). In particular, the DPAS group has a value of 66.5 points $(\mathrm{SD}=12.5)$; the group DA has a value of 70 points (SD $=14.6)$, which is the highest among all groups; control group AA has a median value of 66 points $(\mathrm{SD}=12.08)$. The $\mathrm{CN}$ group has a median of 56 points $(\mathrm{SD}=11.3)$, which is below the maximum allowable norm. As noted above, the group of relatively healthy people has a statistically significant difference in the results of the TAS26 test in comparison with the groups of dependent persons, or the control group (AA). There are no statistically significant differences between the group DA and AA.

Summarizing the above mentioned information, we can establish that people dependent on psychoactive substances have the rate of alexithymia statistically higher than normal, which is expressed in the complication of the feeling of their own experiences and their definition. At the same time, the fact of long-term alcohol non-consumption does not affect a significant decrease in the level of alexithymia: the ability to feel their own feelings still remains impaired, and the person needs to look for ways to compensate for this defect.

We will also analyze the results on the scales of the Five-Factor Personality Questionnaire 5PFQ: Table 2 shows the median values of those scales and subscales of the 5PFQ test, where we have observed statistically significant differences between the following groups: 1) DPAS; 2) DA; 3) AA; 4) CN.

As a result, it was found that in comparison with the DPAS group, CN has a statistically significantly higher level of emotional lability, a more pronounced desire to communicate with others, as well as greater expressiveness, i.e. they are more focused on internal implicit experiences and desires, which manifests in higher sensitivity and plasticity. At the same time, such difference was not found on the fifth scale 5PFQ (Prag-

(C) Telcharov Oleksandr

DOI (article): https://doi.org/10.32626/2227-6246.2021-52.225-252 
DOI: https://doi.org/10.32626/2227-6246.2021-52

2021. випуск 52

matism - Expressiveness) between the control group (AA) and the group of conditional norm.

Table 2

Median values of statistically different scales and subscales of the 5PFQ Five-Factor Personality Questionnaire

\begin{tabular}{|l|c|c|c|c|}
\hline & DPAS & DA & AA & CN \\
\hline $\begin{array}{l}\text { Avoidance of attention - } \\
\text { Attraction of attention }\end{array}$ & 9 & 9 & 10 & 11 \\
\hline $\begin{array}{l}\text { Emotional stability - } \\
\text { Emotional lability }\end{array}$ & 10 & 10 & 11 & 11 \\
\hline Pragmatism - Expressiveness & $\mathbf{4 8}$ & $\mathbf{4 9}$ & $\mathbf{5 4}$ & $\mathbf{5 9}$ \\
\hline Realism - Curiosity & 10 & 10 & 13 & 13 \\
\hline Lack of artistry - Artistry & 10 & 10 & 11 & 12 \\
\hline Insensitivity - Sensitivity & 11 & 10 & 11 & 12 \\
\hline Rigidity - Plasticity & 9 & 9 & 10 & 11 \\
\hline
\end{tabular}

Note: DPAS is a group of dependent to PAS people; DA is a group of dependent on alcohol people at the initial stage of recovery (part of the DPAS group); AA is a group of dependent persons at a later stage of recovery (members of the Alcoholics Anonymous community); $\mathrm{CN}$ is a group of conditional norm without dependence on PAS.

Regarding the differences in the results of the $5 \mathrm{PFQ}$ Five-Factor Personality Questionnaire between the DA and AA groups, statistically significant differences were found in the Pragmatism - Expressiveness factor, namely in the RealismCuriosity subscale. Thus, the results on these scales for representatives of group AA and group CN do not differ significantly, while group DA is less «inquisitive». We can assume that the cessation of alcohol consumption over time has a positive effect on the manifestation of this personal factor and, in this case, the differences may be caused by alcohol dependence, but we cannot confirm this at the moment, so this aspect is the prospect of our future studies.

(C) Telcharov Oleksandr

DOI (article): https://doi.org/10.32626/2227-6246.2021-52.225-252 


\section{Conclusions}

Based on the obtained data, we established a number of features of ToM in individuals dependent on psychoactive substances. In particular, a comparison of groups of people dependent on psychoactive substances was made, and a group of people dependent on alcohol was identified. This group was analyzed separately in the study. We have compared these groups with a control group of individuals at a later stage of recovery (members of the Alcoholics Anonymous community), as well as with a group of conditional norms (representatives of this group have no dependence on any psychoactive substances). A number of statistically significant differences have been found. This makes it possible to describe the specifics of ToM clearly and the affective sphere of persons dependent on psychoactive substances, and persons addicted to alcohol in particular.

The complexity of the allocative perspective in the DPAS group, as well as in the AA group, was established. We can put forward two hypotheses in this regard: 1) the hypothesis of the negative impact of alcohol on the biological substrate responsible for ToM, which is expressed in the difficulty of putting oneself in someone's place. However, we cannot confirm this at the moment, as we have not used the appropriate methods of statistical verification. 2) The hypothesis of the existence of a certain biologically determined factor, which indirectly affects the fact that people dependent on psychoactive substances have similar problems. The psychological manifestation of this factor may be alexithymia or certain alexithymic traits.

It was found that individuals dependent on psychoactive substances do not differ in the results of the alexithymia scale compared with the control group of persons at a later stage of recovery (AA). At the same time in both groups (both DPAS, and AA) high median meanings of alexithymia scale are observed, moderately above the upper limit of the norm, and there is a statistically significant difference between these C Telcharov Oleksandr

DOI (article): https://doi.org/10.32626/2227-6246.2021-52.225-252 
groups and the group of the conditional norm. Obviously, there is a certain biological mechanism, which is associated with a tendency to dependence on alcohol and a difficulty in understanding the emotions, experiences, thoughts and intentions of others. It is also possible that the factor of alcohol consumption impacts these features, but we cannot confirm this with the available research tools.

Statistical analysis has shown differences in SA and AA groups. According to the results of the scale ToMA, the AA group has a better understanding of their own affects, states, experiences and desires; these states are more complex. With the prolonged sobriety, the subjects improve understanding of their own affective manifestations and increase the expressiveness and desire for something new. We assume that these are several complexly interconnected phenomena, in particular, people dependent on psychoactive substances usually have simplified desires associated with the object of their dependence, due to prolonged substances intake they are less able to distinguish their own emotions (both positive and negative), tend to tell more about bodily affective manifestations, not about their own feelings. As their own feelings become relatively closed for them, the factor of pragmatism - expressiveness becomes more rational, emotionless. In this case, we will consider the fifth factor of the 5PFQ Five-Factor Personality Questionnaire as informative at the initial stages of rehabilitation, and we assume that it will be changed in the direction of greater expressiveness with the restoration of the ability to understand one's own experiences.

Summing up, ToM in persons dependent on psychoactive substances (who take substances now or have just recently stopped) is manifested with a reduced understanding of their own experiences (as evidenced by high scores on the TAS-26 test). ToM can be restored when a person is sober for some time, but alexithymia rate remains high anyway. Therefore, there is a certain adaptation towards greater rationality, ana(c) Telcharov Oleksandr

DOI (article): https://doi.org/10.32626/2227-6246.2021-52.225-252 
lysis than feeling. Also, persons, dependent on psychoactive substances, have a complication of the allocative perspective of ToM, even despite a long-term sobriety. As for concomitant factors, there is an increase in emotional stability (the person doesn't understand emotions well, so this doesn't cause any concern, additionally emotions are constrained by rational «reflection» of them). Another concomitant factor is a lower manifestation of the expression factor under the conditions of recent systematic intake of psychoactive substances, which recovers with sobriety increase. However, we cannot confirm certain linear relationships between the severity of this factor and the duration of sobriety at present.

Perspectives for further research include examining the influence of certain factors on the structure of ToM in individuals dependent on psychoactive substances, examining the relationship between the duration of sobriety and the manifestation of the fifth factor of the Five-Factor Personality Questionnaire 5PFQ and increasing homogeneity of the control group.

\section{Literature}

Бурмака Н. П. Психологічні чинники формування алкогольної адиктивної поведінки у підлітків та юнацтва: автореф. дис. ... канд. психол. наук: 19.00.04. Київ : КНУ імені Тараса Шевченка, 2003. $18 \mathrm{c.}$

Возний Д. В. Психоемоційні особливості чоловіків, хворих на алкогольну залежність. Загальна патологія та патологічна фізіологія. 2013. Т. 8. № 3. С. 97-101.

Гапонов К. Д. Алкогольна залежність і соціальний стрес: біохімічні, нейрофізіологічні і психосоціальні механізми взаємовпливу (огляд літератури). Український вісник психоневрологї. 2018. Т. 26. № 1. С. 104-109.

Гусак П. М., Мартинюк Т. А., Сидорук I. I. Профілактика вживання психоактивних речовин підлітками: монографія. Луцьк : ВежаДрук, 2013. 484 с.

Дарвішов Н. Особистісні риси і прийняття рішень у залежних від психоактивних речовин осіб. Збірник наукових пращь «Проблели сучас-

(C) Telcharov Oleksandr

DOI (article): https://doi.org/10.32626/2227-6246.2021-52.225-252 
DOI: https://doi.org/10.32626/2227-6246.2021-52

2021. випуск 52

ної психологї». Кам'янець-Подільський : Аксіома, 2019. Вип. 46. C. 88-113. DOI https://doi.org/10.32626/2227-6246.2019-46.88-113.

Дубяга Е. В., Мещеряков Б. Г. Имплицитная теория разума: краткий обзор. Психологический журнал Международного университета природы, общества и человека. 2010. № 1. URL : https://psyanima. $\mathrm{su} /$ journal/2010/1/2010n1a4/2010n1a4.pdf.

Ересько Д. Б., Исурина Г. Л., Кайдановская Е. В., Карвасарский Б. Д., Карпова Э. Б., Смирнова Т. Г., Шифрин В. Б. Алекситимия и методы ее определения при пограничных психосоматических расстройствах. Санкт-Петербург : Санкт-Петербургский научно-исследовательский психоневрологический институт имени В. М. Бехтерева, 2005. 25 с.

Марценковський I. А., Марценковська I. I. Стабілізатори настрою: дискусійні питання терапії алкогольної залежності. Міжнародний неврологічний журнал. 2019. № 3. С. 70-76.

Мінко О. І., Лісна Н. М., Маркозова Л. М. Індивідуально-психологічні особливості осіб з алкогольною залежністю та їх співзалежних родичів, які впливають на формування терапевтичного альянсу. Украӥнський вісник психоневрології. 2018. Т. 26. № 3. С. 39-42.

Пінчук І. Я., Колодєжний О. В., Петриченко О. О., Здорик І. Ф. Аналіз статистичних показників розладів психіки та поведінки внаслідок уживання психоактивних речовин у 2015-2016 роках. Архів ncuxiampiï. 2017. Т. 23. № 4. С. 252-260.

Хромов А. Б. Пятифакторный опросник личности: учеб.-метод. пособие. Курган : Курганский государственный университет, 2000. 23 с.

Чемерис Н. М. Медико-соціальні аспекти проблеми вживання психоактивних речовин молоддю (огляд наукової літератури). Україна. Здоров’я нації. 2017. № 3. С. 285-291.

Щербина Л. Ф. Динаміка смислових структур осіб, залежних від психоактивних речовин, у процесі психологічної реабілітації: автореф. дис. ... канд. психол. наук: 19.00.04. Київ : КНУ імені Тараса Шевченка, 2004. 21 с.

Bosco, F. M., Capozzi, F., Colle, L., Marostica, P., \& Tirassa, M. (2014). Theory of mind deficit in subjects with alcohol use disorder: an analysis of mindreading processes. Alcohol and Alcoholism. Vol. 49. No. 3. C. 299-307.

Bosco, F. M., Gabbatore, I., Tirassa, M., \& Testa, S. (2016). Psychometric properties of the Theory of Mind Assessment Scale in a sample of adolescents and adults. Frontiers in psychology. Vol. 7. No. 7. P. 1-12. Goldman, A. (2012). Theory of Mind. Oxford Handbook of Philosophy and Cognitive Science. Oxford : Oxford University Press. P. 402-424.

(C) Telcharov Oleksandr

DOI (article): https://doi.org/10.32626/2227-6246.2021-52.225-252 
DOI: https://doi.org/10.32626/2227-6246.2021-52

2021. випУСК 52

Gweon, H., \& Saxe, R. (2013). Developmental cognitive neuroscience of theory of mind. Neural circuit development and function in the brain. No. 3. P. 367-377.

Jacobs, E., \& Nader-Grosbois, N. (2020). Affective and Cognitive Theory of Mind in children with intellectual disabilities: how to train them to foster social adjustment and emotion regulation. J. Educ. Train. Stud. No. 8. P. 80-97.

Minnaard, A. M. (2020). Loss of control over substance use: Preclinical studies into the behavioural and neural mechanisms of addiction. Extended abstract of doctor's thesis. Utrecht : Utrecht University. DOI 10.33540/163.

Onuoha, R. C., Quintana, D. S., Lyvers, M., \& Guastella, A. J. (2016). A Meta-analysis of Theory of Mind in Alcohol Use Disorders. Alcohol and Alcoholism. Vol. 51. No. 4. P. 410-415. DOI 10.1093/alcalc/ agv137.

Premack, D., \& Woodruff, G. (1978). Does the chimpanzee have a theory of mind? Behavioral and brain sciences. Vol. 1. No. 4. P. 515-526.

Schiffer, B., Pawliczek, C., Müller, B. W., Wiltfang, J., Brüne, M., Forsting, M., \& Hodgins, S. (2017). Neural mechanisms underlying affective theory of mind in violent antisocial personality disorder and / or schizophrenia. Schizophrenia bulletin. Vol. 43. No. 6. P. 1229-1239.

Sprong, M., Schothorst, P., Vos, E., Hox, J., \& Engeland, H. (2007). Theory of mind in schizophrenia: meta-analysis. British Journal of Psychiatry. Vol. 191. P. 5-13.

Svanberg, J. (2018). The psychology of addiction. London; New York : Routledge, Taylor \& Francis Group. 128 p.

\section{References}

Burmaka, N. P. (2003). Psykholohichni chynnyky formuvannia alkoholnoi adyktyvnoi povedinky u pidlitkiv ta yunatstva [Psychological factors of formation of alcohol addictive behavior in adolescents and youth]. Extended abstract of candidate's thesis. Kyiv : KNU imeni Tarasa Shevchenka [in Ukrainian].

Voznyi, D. V. (2013). Psykhoemotsiini osoblyvosti cholovikiv, khvorykh na alkoholnu zalezhnist [Psycho-emotional features of men with alcohol dependence]. Zahalna patolohiia ta patolohichna fiziolohiia - General pathology and pathological physiology, 8 (3), 97-101 [in Ukrainian].

Haponov, K. D. (2018). Alkoholna zalezhnist i sotsialnyi stres: biokhimichni, neirofiziolohichni i psykhosotsialni mekhanizmy vzaiemovplyvu (ohliad literatury) [Dependence on alcohol and social stress: biochemi-

(C) Telcharov Oleksandr

DOI (article): https://doi.org/10.32626/2227-6246.2021-52.225-252 
DOI: https://doi.org/10.32626/2227-6246.2021-52 2021. ВИПУСК 52

cal, neurophysiological and psychosocial mechanisms of interplay (literature review)]. Ukrainskyi visnyk psykhonevrolohii - Ukrainian visnyk of psychoneurology, 26 (1), 104-109 [in Ukrainian].

Husak, P. M., Martyniuk, T. A., \& Sydoruk, I. I. (2013). Profilaktyka vzhyvannia psykhoaktyvnykh rechovyn pidlitkamy [Prevention of substance use by adolescents]. Lutsk : Vezha-Druk [in Ukrainian].

Darvishov, N. (2019). Osobystisni rysy i pryiniattia rishen u zalezhnykh vid psykhoaktyvnykh rechovyn osib [Personality traits and decision making of substance addicts]. Zbirnyk naukovykh prats «Problemy suchasnoi psykholohii» - Collection of research papers "Problems of Modern Psychology», 46, 88-113. DOI https://doi.org/10.32626/ 2227-6246.2019-46.88-113 [in Ukrainian].

Dubiaga, E. V., \& Meshcheriakov, B. G. (2010). Implitsitnaia teoriia razuma: kratkii obzor [Theory of Mind: a brief review]. Psikhologicheskii zhurnal Mezhdunarodnogo universiteta prirody, obshchestva $i$ cheloveka - Psychological journal of Internetional university of nature, society and human, (Vol. 1). Retrieved from https://psyanima. $\mathrm{su} /$ journal/2010/1/2010n1a4/2010n1a4.pdf [in Russian].

Eresko, D. B., Isurina, G. S., Kaidanovskaia, E. V., Karvasarskii, B. D., Karpova, Ye. B., Korepanova, T. G., \& Shifrin, V. B. (2005). Aleksitimiia $i$ metody yeie opredeleniia pri pogranichnykh psikhosomaticheskikh rasstroistvakh [Alexithymia and methods of its definition at borderline psychosomatic disorders]. Sankt-Peterburg [in Russian].

Martsenkovskyi, I. A., \& Martsenkovska, I. I. (2019). Stabilizatory nastroiu: dyskusiini pytannia terapii alkoholnoi zalezhnosti [Mood stabilizers: controversial issues in the treatment of alcohol dependence]. Mizhnarodnyi nevrolohichnyi zhurnal - International neurological journal, 3, 70-76 [in Ukrainian].

Minko, O. I., Lisna, N. M., \& Markozova, L. M. (2018). Indyvidualnopsykholohichni osoblyvosti osib z alkoholnoiu zalezhnistiu ta yikh spivzalezhnykh rodychiv, yaki vplyvaiut na formuvannia terapevtychnoho aliansu [Individual psychological characteristics of people with dependence on alcohol and their interdependent relatives, that influence the formation of a therapeutic alliance]. Ukrainskyi visnyk psykhonevrolohii - Ukrainian visnyk of psychoneurology, 26 (3), 3942 [in Ukrainian].

Pinchuk, I. Ya., Kolodiezhnyi, O. V., Petrychenko, O. O., \& Zdoryk, I. F. (2017). Analiz statystychnykh pokaznykiv rozladiv psykhiky ta povedinky vnaslidok uzhyvannia psykhoaktyvnykh rechovyn u 20152016 rokakh [Analysis of statistical indicators of mental and behavioral disorders due to the use of psychoactive substances in 2015(C) Telcharov Oleksandr

DOI (article): https://doi.org/10.32626/2227-6246.2021-52.225-252 http://journals.uran.ua/index.php/2227-6246 
2016]. Arkhiv psykhiatrii - Archive of psychiatry, 23 (4), 252-260 [in Russian].

Khromov, A. B. (2000). Piatifaktornyi oprosnik lichnosti [Five-factor personality questionnaire]. Kurgan : Kurganskii gosudarstvennyi universitet [in Russian].

Chemerys, N. M. (2017). Medyko-sotsialni aspekty problemy vzhyvannia psykhoaktyvnykh rechovyn moloddiu [Medical-social aspects of the problem of psychoactive substance use by young people]. Ukraina. Zdorovia natsii - Ukraine. Health of the nation, 3, 285-291 [in Ukrainian].

Shcherbyna, L. F. (2004). Dynamika smyslovykh struktur osib, zalezhnykh vid psykhoaktyvnykh rechovyn, u protsesi psykholohichnoi reabilitatsii [Dynamics of semantic structures of persons addicted to psychoactive substances in the process of psychological rehabilitation]. Extended abstract of candidate's thesis. Kyiv : KNU imeni Tarasa Shevchenka [in Ukrainian].

Bosco, F. M., Capozzi, F., Colle, L., Marostica, P., \& Tirassa, M. (2014). Theory of mind deficit in subjects with alcohol use disorder: an analysis of mindreading processes. Alcohol and Alcoholism, 49 (3), 299-307.

Bosco, F. M., Gabbatore, I., Tirassa, M., \& Testa, S. (2016). Psychometric properties of the Theory of Mind Assessment Scale in a sample of adolescents and adults. Frontiers in psychology, 7 (7), 1-12.

Goldman, A. (2012). Theory of Mind. Oxford Handbook of Philosophy and Cognitive Science, (pp. 402-424). Oxford : Oxford University Press.

Gweon, H., \& Saxe, R. (2013). Developmental cognitive neuroscience of theory of mind. Neural circuit development and function in the brain, 3, 367-377.

Jacobs, E., \& Nader-Grosbois, N. (2020). Affective and Cognitive Theory of Mind in children with intellectual disabilities: how to train them to foster social adjustment and emotion regulation. J. Educ. Train. Stud, 8, 80-97.

Minnaard, A. M. (2020). Loss of control over substance use: Preclinical studies into the behavioural and neural mechanisms of addiction. Extended abstract of doctor's thesis. Utrecht : Utrecht University. DOI 10.33540/163.

Onuoha, R. C., Quintana, D. S., Lyvers, M., \& Guastella, A. J. (2016). A Meta-analysis of Theory of Mind in Alcohol Use Disorders. Alcohol and Alcoholism, 51 (4), 410-415. DOI 10.1093/alcalc/agv137.

Premack, D., \& Woodruff, G. (1978). Does the chimpanzee have a theory of mind? Behavioral and brain sciences, 1 (4), 515-526.

(C) Telcharov Oleksandr

DOI (article): https://doi.org/10.32626/2227-6246.2021-52.225-252 
Schiffer, B., Pawliczek, C., Müller, B. W., Wiltfang, J., Brüne, M., Forsting, M., ... \& Hodgins, S. (2017). Neural mechanisms underlying affective theory of mind in violent antisocial personality disorder and / or schizophrenia. Schizophrenia bulletin, 43 (6), 1229-1239.

Sprong, M., Schothorst P., Vos, E., Hox, J., \& Engeland, H. (2007). Theory of mind in schizophrenia: meta-analysis. British Journal of Psychiatry, 191, 5-13.

Svanberg, J. (2018). The psychology of addiction. London; New York : Routledge, Taylor \& Francis Group.

Тельчаров Олександр. Імпліцитна теорія свідомості при залежності від психоактивних речовин та в умовах норми

\section{АНОТАЦІЯ}

Meта статmi - порівняти особливості ITC в осіб, залежних від ПАР, на різних етапах одужання й у групі умовної норми. Дослідження проводилося на 98 особах.

За різними параметрами порівнювалися: 1) пацієнти реабілітаційного центру, які мають залежність від алкоголю або / та від інших ПАР і перебувають на ранньому етапі одужання; 2) особи, залежні від алкоголю, які є частиною першої групи; 3) особи, залежні від алкоголю, на пізніших етапах одужання (члени Співтовариства анонімних алкоголіків); 4) особи, які належать до групи умовної норми.

Методи. Використано методику Theory of Mind assessment scale (Th.o.m.a.s, Bosco, Gabbatore, Tirassa \& Testa, 2016); Торонтську Алекситимічну шкалу ТАС26, адаптовану в НДІ ім. Бехтерєва (Ересько, Исурина, Кайдановская, Карвасарский, Карпова, Смирнова \& Шифрин, 2005); П’ятифакторний особистісний опитувальник 5PFQ, адаптований Хромовим (Хромов, 2000). Для аналізу отриманих даних використано описові статистики, а також непараметричні критерії: U-критерій Манна-Вітні й Тест Колмогорова-Смірнова.

Результати дослідження. Знайдено низку статистично значущих відмінностей між 4 групами, зокрема у структурі ITC, вираженості алекситимії, а також у силі прояву різних чинників і субчинників за особистісним опитувальником 5PFQ. Установлено ускладненість алокативної перспективи як у пацієнтів реабілітаційного центру, так і в осіб, які перебувають на пізніших етапах одужання та є членами Співтовариства анонімних алкоголіків. Установлено, що ці дві групи не відрізняються за (C) Telcharov Oleksandr

DOI (article): https://doi.org/10.32626/2227-6246.2021-52.225-252 
DOI: https://doi.org/10.32626/2227-6246.2021-52

2021. вИПУСК 52

результатами Торонтської алекситимічної шкали, проте водночас в обох групах спостерігаються високі медіанні показники, помірно вищі за верхню межу норми, і статистично значуща відмінність між зазначеними групами та групою умовної норми.

Висновки. ІТС в осіб, залежних від ПАР, вирізняється редукованим розумінням власних переживань, за умови, якщо вживання ПАР триває або припинилося нещодавно, проте відновлюється з плином часу тверезості; при цьому високий показник алекситимії зберігається. Також в осіб, залежних від ПАР, спостерігається ускладнення алокативної перспективи ITC навіть за умов довготривалої тверезості.

Ключові слова: особи, залежні від психоактивних речовин, члени Співтовариства анонімних алкоголіків, імпліцитна теорія свідомості, алекситимія, алокативна перспектива, особистісні чинники.

\section{Тельчаров Александр. Имплицитная теория разума при зависимости от психоактивных веществ и в условиях нормы}

\section{АННОТАЦИЯ}

Целью статьи является сравнение ИТС у людей, зависимых от ПАВ, на разных этапах выздоровления и в группе условной нормы. Исследование проводилось на 98 лицах.

По разным параметрам сравнивались: 1) пациенты реабилитационного центра, зависимые от алкоголя и / или других ПАВ и пребывающие на раннем этапе выздоровления; 2) лица, зависимые от алкоголя, которые являются частью первой группы; 3) лица, зависимые от алкоголя на более поздних этапах выздоровления (члены Сообщества анонимных алкоголиков); 4) лица, принадлежащие группе условной нормы.

Методы. Использовано методику Theory of Mind assessment scale (Th.o.m.a.s, Bosco, Gabbatore, Tirassa \& Testa, 2016); Торонтскую Алекситимическую шкалу ТАС26, адаптированную в НИИ им. Бехтерева (Ересько, Исурина, Кайдановская, Карвасарский, Карпова, Смирнова \& Шифрин, 2005), Пятифакторный личностный опросник 5PFQ в адаптации Хромова (Хромов, 2000). Для анализа полученных данных использованы описательные статистики, а также непараметрические критерии: U-критерий Манна - Уитни и Тест Колмогорова - Смирнова.

Результаты исследования. Найдено ряд статистически значимых отличий между 4 группами, в частности в структуре ИТС, выраженнос(C) Telcharov Oleksandr DOI (article): https://doi.org/10.32626/2227-6246.2021-52.225-252 
DOI: https://doi.org/10.32626/2227-6246.2021-52

2021. випУСК 52

ти алекситимии, а также в силе проявления разных факторов и субфакторов по личностному опроснику 5PFQ. Установлено утрудненность аллокативной перспективы как у пациентов реабилитационного центра, так и у лиц, пребывающих на более поздних этапах выздоровления и являющихся членами Сообщества анонимных алкоголиков. Установлено, что эти две группы не отличаются по результатам Торонтской Алекситимической шкалы, при том, что в обеих группах наблюдаются высокие медианные показатели, умеренно выше верхней границы нормы, и статистически значимое отличие между данными группами и группой условной нормы.

Выводы. ИТС улии, зависимых от ПАВ, отличается редуцированным пониманием собственных переживаний, при условии если употребление ПАВ продолжается или прекратилось недавно, но восстанавливается с длительностью трезвости; при этом высокий показатель алекситимии сохраняется. Также у лии, зависимых от ПАВ, наблюдается усложненность аллокативной перспективы ИТС даже при условии длительной трезвости.

Ключевые слова: лица, зависимые от психоактивных веществ, члены Сообщества анонимных алкоголиков, имплицитная теория сознания, алекситимия, аллокативная перспектива, личностные факторы.

Original manuscript received February 27, 2021 Revised manuscript accepted March 30, 2021 